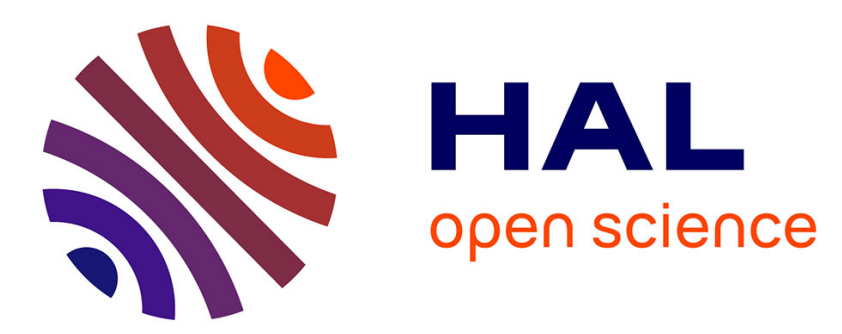

\title{
Models for predicting microfibril angle variation in Scots pine
}

David Auty, Barry Gardiner, Alexis Achim, John Moore, Andrew Cameron

\section{To cite this version:}

David Auty, Barry Gardiner, Alexis Achim, John Moore, Andrew Cameron. Models for predicting microfibril angle variation in Scots pine. Annals of Forest Science, 2013, 70 (2), pp.209-218. 10.1007/s13595-012-0248-6 . hal-01201467

\section{HAL Id: hal-01201467 \\ https://hal.science/hal-01201467}

Submitted on 17 Sep 2015

HAL is a multi-disciplinary open access archive for the deposit and dissemination of scientific research documents, whether they are published or not. The documents may come from teaching and research institutions in France or abroad, or from public or private research centers.
L'archive ouverte pluridisciplinaire HAL, est destinée au dépôt et à la diffusion de documents scientifiques de niveau recherche, publiés ou non, émanant des établissements d'enseignement et de recherche français ou étrangers, des laboratoires publics ou privés.

$$
\text { Copyright }
$$




\title{
Models for predicting microfibril angle variation in Scots pine
}

\author{
David Auty • Barry A. Gardiner • Alexis Achim • \\ John R. Moore • Andrew D. Cameron
}

Received: 3 April 2012 /Accepted: 8 October 2012 /Published online: 6 November 2012

(C) INRA and Springer-Verlag France 2012

\begin{abstract}
- Context Microfibril angle (MFA) is one of the key determinants of solid timber performance due to its strong influence on the stiffness, strength, shrinkage properties and dimensional stability of wood.
\end{abstract}

\section{Handling Editor: Jean-Michel Leban}

Contribution of the co-authors D. Auty was primarily responsible for conducting the field work, data analysis, and writing the manuscript and preparing figures. B. Gardiner was co-supervisor of the project and contributed to the writing and editing of the manuscript. A. Achim contributed to the model development and writing and editing of the manuscript. J. Moore contributed to the data analysis and editing of the manuscript. A. Cameron was co-supervisor of the project and contributed to the editing of the manuscript.

\section{Auty $(\bowtie) \cdot$ B. A. Gardiner \\ Forest Research, \\ Roslin, Midlothian, \\ EH25 9SY, Scotland, UK \\ e-mail: auty.david.1@ulaval.ca}

\section{A. Achim}

Département des sciences du bois et de la forêt, Université Laval, Québec G1V 0A6, Canada

\section{J. R. Moore}

Scion (New Zealand Forest Research Institute Limited),

Private Bag 3020, Rotorua 3046, New Zealand

\section{A. D. Cameron}

University of Aberdeen,

Cruickshank Building, St Machar Drive, Aberdeen,

AB24 3UU, Scotland, UK

Present Address:

D. Auty

Département des sciences du bois et de la forêt, Université Laval, Québec G1V 0A6, Canada

Present Address:

B. A. Gardiner

INRA-Unité EPHYSE,

71 Avenue Edouard Bourlaux, Villenave D’Ornon,

33140, Bordeaux, France
- Aims The aim of this study was to develop a model for predicting MFA variation in plantation-grown Scots pine (Pinus sylvestris L). A specific objective was to quantify the additional influence of growth rate on the radial variation in MFA.

- Methods Twenty-three trees were sampled from four mature Scots pine stands in Scotland, UK. Pith-to-bark MFA profiles were obtained on 69 radial samples using scanning $\mathrm{X}$-ray diffractometry. A nonlinear mixed-effects model based on a modified Michaelis-Menten equation was developed using cambial age and annual ring width as explanatory variables.

- Results The largest source of variation in MFA ( $>90 \%)$ was within trees, while between-tree variation represented just $7 \%$ of the total. Microfibril angle decreased rapidly near the pith before reaching stable values in later annual rings. The effect of ring width on MFA was greater at higher cambial ages.

- Conclusion A large proportion of the variation in MFA was explained by the fixed effects of cambial age and annual ring width. The final model is intended for integration into growth, yield and wood quality simulation systems.

Keywords Microfibril angle $\cdot$ Pinus sylvestris $\cdot$ Nonlinear mixed-effects models $\cdot$ Radial variation $\cdot$ Growth rate $\cdot$ Ring width

\section{Introduction}

Microfibril angle (MFA) - the average orientation of the cellulose microfibrils in the $S_{2}$ layer of the wood cell wall with respect to the longitudinal axis - is one of the key determinants of solid timber performance due to its strong influence on the stiffness, strength, shrinkage properties and dimensional stability of structural lumber (Cave 1969; Meylan 1972; Bendtsen and Senft 1986; Cave and Walker 1994). In a single 
tree, MFA, along with other microstructural properties that influence sawn timber performance, such as tracheid dimensions and cell wall thickness, shows distinctive systematic variation with cambial age and height in the stem (Megraw 1985). This results in the formation of a 'juvenile' core of wood, which has characteristics that negatively affect mechanical properties (e.g. Zobel and Sprague 1998; Larson et al. 2001; Burdon et al. 2004; Cameron et al. 2005; Mansfield et al. 2009).

Increasing demand for wood and wood products in recent decades has been mirrored by a general trend towards wider initial spacing and shorter rotation lengths in plantationgrown conifers, leading to trees with proportionally larger juvenile cores and larger branches (Kennedy 1995). This means that a substantial quantity of juvenile wood will be converted into sawn timber, leading to an increase in failure rates for structural strength classes in machine grading. Such a reduction in structural timber yields is likely to carry an associated economic cost for the wood processing industries (Walker and Butterfield 1996).

Recent advances in measurement techniques, such as automated scanning X-ray diffractometry (Evans et al. 1995), reflect the increasing importance of MFA to the forest products industry. Consequently, it is now widely regarded, along with wood density, as one of the most significant wood properties influencing the end-use performance of solid wood (Evans and Ilic 2001; Downes et al. 2002; McLean et al. 2010). In conifers, values of MFA are generally higher near the pith (typically $25^{\circ}$ to $30^{\circ}$ in the first few growth rings) and decline rapidly in the first 10 to 15 growth rings before approaching a more stable value $\left(\approx 10^{\circ}\right.$ to $\left.12^{\circ}\right)$ in the mature wood (e.g. Barnett and Bonham 2004; Jordan et al. 2005; Alteyrac et al. 2006). This radial pattern is repeated irrespective of height in the tree, although the rate of decrease near the pith can vary with sampling height (Megraw 1985).

Although within-stem changes account for a large proportion of the total variation in MFA, there are also differences among trees within stands (Jordan et al. 2006). In radiata pine (Pinus radiata D. Don), such differences are notably more pronounced in the juvenile wood zone (Donaldson 1992; Cown et al. 1999). Since MFA has relatively high broad sense heritability (Donaldson and Burdon 1995: Cown et al. 2004), there is also significant variation in MFA between different provenances within a species (Vainio et al. 2002) and between trees growing in different physiographic regions (Jordan et al. 2006, 2007).

Despite these findings, there is still relatively little information available about the influence of growth rate on MFA variation in many important commercial timber species. A significant and positive effect of growth rate on MFA has been reported in Norway spruce (Picea abies L. Karst.) (Herman et al. 1999), with fast-grown trees having a mean
MFA of $29^{\circ}$, compared with $21^{\circ}$ in slow-grown trees. Similar results were found by Lundgren (2004) in the same species, who observed a significant increase in MFA after the application of fertiliser and irrigation treatments. Sarén et al. (2004) also found that mean MFA decreased more gradually with distance from the pith in fast-grown Norway spruce trees compared with trees growing on a medium fertility site. Similarly, growth rate was found to be positively related to MFA in Eucalyptus nitens following water stress release (Wimmer et al. 2002). One possible explanation for these results is that enhanced growth leads to an increase in the proportion of shorter, larger-diameter and thinner-walled earlywood-type cells (Larson 1969), which tend to have higher microfibril angles (Panshin and de Zeeuw 1980).

The aforementioned studies highlight the possibility of influencing MFA using silvicultural techniques that suppress juvenile growth, leading to a greater quantity of wood with lower MFA in mature trees (Lindström et al. 1998). However, despite the increasing recognition of the relationship between tree growth and this important wood quality trait, predictive models for MFA that explicitly include growth rate variables are still relatively scarce in the literature. Furthermore, while environmental conditions such as site quality, day length and growth rate are thought to play a role in MFA variation (e.g. Wimmer et al. 2002; Clark III et al. 2006), the relative magnitude of, and interaction between, site factors and genotypic effects are not fully understood (Donaldson 1992; Lasserre et al. 2009). Compression wood formation in stems subjected to wind loading or other environmental stresses (Timmell 1986) also distorts the general pith-to-bark trend in MFA because values tend to be high in compression wood compared with normal wood cells (Gardiner and Macdonald 2005).

Empirical models for predicting the within-stem variation in MFA and other important wood quality attributes are of value to forest managers because they can be integrated into growth and yield simulation systems and used to predict the effects of forest management practices on end-use properties (Houllier et al. 1995; Macdonald et al. 2010). Such models have been developed for many commercially important timber species (Verkasalo and Leban 2002; Jordan et al. 2005; Achim et al. 2006; Moore et al. 2009a; McLean et al. 2010; Gardiner et al. 2011; Watt et al. 2011), and can be used to predict structural timber yields and to provide important information for early selection of desirable wood quality traits (Lee 1999; Moore et al. 2009b; Lenz et al. 2011).

The aim of this study was to develop a model for predicting MFA variation in the stems of plantation-grown Scots pine (Pinus sylvestris L), with the specific objective of quantifying the additional influence of growth rate on the radial pattern of variation. A nonlinear mixed-effects model was developed which used cambial age and annual ring 
width as independent variables. Predicted values from the final model are graphically presented to show the potential for integrating the developed equations into growth and yield simulation systems.

\section{Materials and methods}

\subsection{Study sites}

The study material was obtained from four even-aged mature Scots pine stands located in northeast Scotland. The sites were established on freely draining podzolic or sandy soils with a mean accumulated temperature ranging from 1,037 to 1,261 day-degrees $>5{ }^{\circ} \mathrm{C}$. Mean moisture deficit (potential evaporation minus monthly rainfall) ranged from 84 to $135 \mathrm{~mm}$. Stand age ranged from 68 to 100 years, with a mean of 80 years. The stand densities at each site indicated that the stands had previously been thinned, but the initial planting spacing and precise thinning history were unknown. However, it was known that none of the sites had been thinned for at least 3 years prior to sampling.

\subsection{Sample tree measurements}

In the summer of 2008 , ten randomly located temporary sample plots were installed in each stand. Plot area was either 0.02 or 0.05 ha depending on current stand density, in order to ensure that between 7 and 20 trees were sampled in accordance with UK inventory practice. The diameter at breast height (DBH, measured $1.3 \mathrm{~m}$ above ground level) and total height were measured on all trees in each of the sample plots. Sample tree mean DBH ranged from 19.6 to $53.0 \mathrm{~cm}$, and mean total height from 12.6 to $26.3 \mathrm{~m}$ (Table 1). Six trees from each site - two from each diameter quartile, excluding the lowestwere then randomly selected for destructive sampling. After felling, 10-15-cm-thick transverse discs were cut from five positions along the stem, at approximately $1.3 \mathrm{~m}, 5 \mathrm{~m}$, and the crown base, crown midpoint and upper crown. Sampling heights were adjusted to avoid branch whorls or stem damage, which may locally influence wood properties (Auty et al. 2011). In total, 120 discs were sampled from 24 trees, representing five sampling heights along the stem.

\subsection{SilviScan-3 sample preparation and scanning}

The SilviScan-3 instrument (Innventia AB, Stockholm) is designed to analyse radial samples measuring $2 \mathrm{~mm}$ in the tangential direction and $7 \mathrm{~mm}$ in the longitudinal direction. North-facing radial sections with cross-sectional dimensions of approximately $15 \times 15 \mathrm{~mm}$ were cut from each sample disc and soaked in clean acetone for three separate 24$\mathrm{h}$ periods to remove extractives. The north direction was

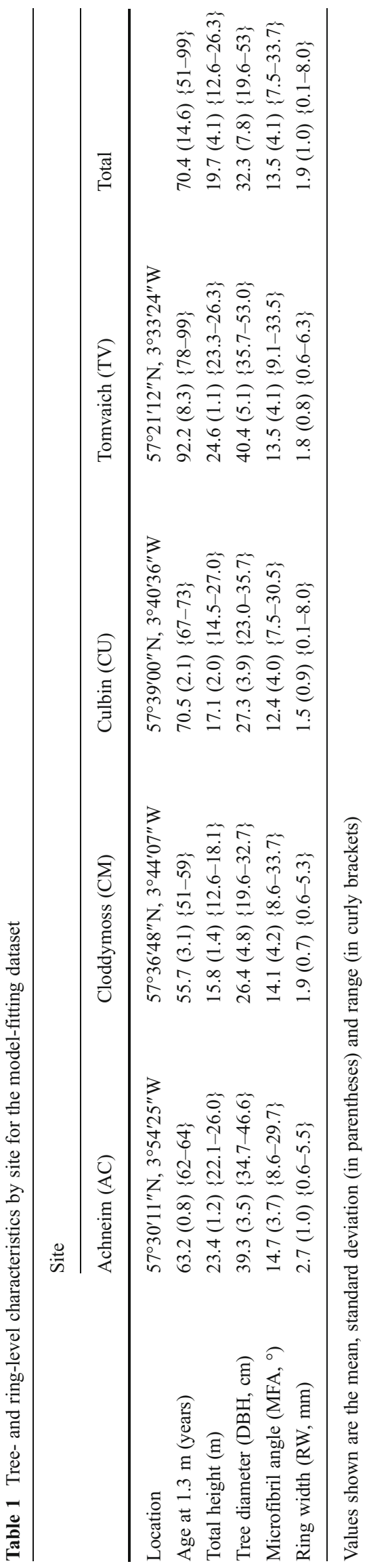


selected to control for possible compression wood formation in the leeward side of leaning stems due to the prevailing westerly or south-westerly winds in northern Britain. Samples were then passed through a series of automated twinblade circular saws, which made the 2- and 7-mm cuts in the appropriate orientations. Any remaining bark was removed, and the samples were Soxhlet extracted in acetone for approximately $12 \mathrm{~h}$ to remove any residual extractives. Before scanning, specimens were conditioned in the laboratory at approximately $22{ }^{\circ} \mathrm{C}$ and $40 \%$ relative humidity until they reached constant mass, resulting in a testing moisture content of approximately $7-8 \%$. Samples were scanned in the radialtangential direction using an X-ray diffractometer, and the mean MFA was calculated over 5-mm intervals along the length of each sample. Analysis of the diffraction profiles provides information about the orientation and distribution of the cellulose microfibrils in the $\mathrm{S}_{2}$ layer of the secondary cell wall (Evans 1999). Additional information, including ring width, cell dimensions and density, was obtained using image analysis and scanning X-ray densitometry.

\subsection{Statistical analysis}

The hierarchical structure of the data (radial and longitudinal variation within a single tree, between trees growing on a particular site and between-site differences) enables the application of mixed-effects modelling techniques, which take into account these multiple sources of variation and the mutual dependence among observations, allowing more accurate estimation of parameter standard errors (Lindström and Bates 1990). Thus, random site, tree and disc effects were included in the models in order to allow parameter estimates to vary around the population mean (i.e. fixed effects) at the level of each grouping factor (Jordan et al. 2005; Gardiner et al. 2011). Mixed models can easily handle unbalanced data and also allow for an appropriate variance function and correlation structure to be included, in order to model heteroscedasticity (non-constant variance of the within-group errors) and dependence among within-group errors, respectively (Pinheiro and Bates 2000).

Model selection was based on visual analysis of plots of the normalised residuals versus fitted and explanatory variables (Pinheiro and Bates 2000) and Akaike's information criterion (AIC, Akaike 1974), which measures the relative adequacy of different nested models. AIC is used when comparing models fitted to the same dataset, and as a rule, the model with the lower AIC is preferred. Chi-squared-based likelihood ratio tests were used to evaluate the significance of terms in both the fixed and the random effects structure, and also to test the significance of the variance function and correlation structure. Parameter estimates were obtained using the maximum likelihood method, and only those parameters that were significant $(p<0.05)$ were retained in the final models.
Model performance was evaluated by calculating the mean absolute error $(|E|)$ and mean percentage error $(E \%)$ from the fixed part of each model. Two sets of fit indices $\left(R^{2}\right)$ were also calculated using the equations given in Parresol (1999). In the first set, the predicted values were estimated from only the fixed effects terms of each model, and in the second, they were calculated from both the fixed and random effects. All statistical analyses were carried out using functions contained in the nlme library (Pinheiro et al. 2012) of the R statistical programming environment (R Development Core Team 2012).

\section{Model development}

The variation in MFA with cambial age (i.e. annual ring number from the pith) is curvilinear, taking the form of a negative exponential curve. Values tend to be high near to the pith but decrease rapidly before reaching more stable values in mature wood. In addition, MFA generally increases with increasing annual ring width. Although every effort was made to avoid compression wood during the sample preparation stage, initial data exploration revealed that of the 120 prepared samples, 51 had atypical pith-to-bark patterns, with very high values in a large proportion of mature growth rings (e.g. MFA $>30^{\circ}$ at cambial age 20 or MFA $>20^{\circ}$ at cambial age 40). Because such patterns are likely to be attributable to the presence of compression wood (Gardiner and Macdonald 2005), these samples were omitted from the model-fitting dataset. In the remaining samples, the first and last annual rings were also omitted from the analysis due to the uncertainty in measurements taken in rings adjacent to the pith and bark. Data from 69 radial samples were used for model construction, which contained MFA information from a total of 3,030 annual rings from 23 trees. Mean tree- and ring-level characteristics for the model-fitting dataset are presented in Table 1, and scatterplots showing the variation in MFA with cambial age and annual ring width are presented in Fig. 1.

\subsection{Variance components model}

In order to estimate the variance components of each level of the random effects, an intercept-only linear mixed-effects model was fitted to the MFA data. The model describes the log-transformed response of mean MFA $y_{i j k l}$ measured on the $l$ th annual ring of the $k$ th disc from the $j$ th tree at the $i$ th site. Using the notation of Pinheiro and Bates (2000), this model is expressed as:

$y_{i j k l}=\mu+b_{i}+b_{i j}+b_{i j k}+\varepsilon_{i j k l}$

where $\mu$ denotes the model intercept or grand mean, $b_{i}$ denotes the site random effect $(i=1, \ldots, 4), b_{i j}$ denotes the 

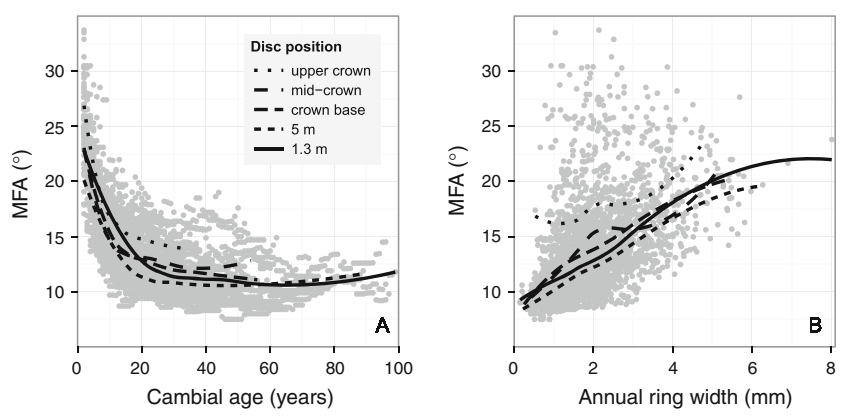

Fig. 1 MFA plotted against A) cambial age and B) annual ring width, by approximate sampling position. Lines represent loess smoothing functions through observations at each sampling height

tree nested in site random effect $(j=1, \ldots, 23), b_{i j k}$ the disc nested in tree within site random effect $(k=1, \ldots, 69)$ and $\varepsilon_{i j k l}$ represents the within-group errors. The random effects and within-group errors were assumed to be independent and multivariately normally distributed, with $b_{i} \sim N\left(0, \Psi_{1}\right), b_{i j} \sim N$ $\left(0, \Psi_{2}\right), b_{i j k} \sim N\left(0, \Psi_{3}\right)$ and $\varepsilon_{i j k l} \sim N\left(0, \sigma_{e}{ }^{2}\right)$. The $\Psi_{1}, \Psi_{2}$ and $\Psi_{2}$ are the variance-covariance matrices for the different levels of random effects-site, tree and disc, respectively. The contribution of each level of variation was calculated as a percentage of the total random variation in the interceptonly model.

\subsection{Mixed-effects model specification}

Various nonlinear functional forms were screened during the model fitting process, including the modified threeparameter logistic function presented in Jordan et al. (2005) for modelling variation in MFA with cambial age in loblolly pine (Pinus taeda L.). The logistic function tends to a lower asymptote with increasing annual ring number, and is expressed as:

$y_{i j k l}=\frac{\alpha_{0}}{1+e^{\alpha_{1} \cdot C A_{j k l}}}+\alpha_{2}+a_{2, i}+a_{2, i j}+a_{2, j i k}+\varepsilon_{i j k l}$

where $y_{i j k l}$ is the mean MFA (degree) in each annual growth ring, $\mathrm{CA}_{i j k l}$ is the cambial age (years) of the $l$ th annual ring of the $k$ th disc from the $j$ th tree at the $i$ th site, $\alpha_{0}, \alpha_{1}$ and $\alpha_{2}$ the fixed effects parameters to be estimated, representing the initial value near the pith, the rate parameter and the lower asymptote, respectively. Since $\alpha_{2}$ assumes a constant value across all cambial ages, this parameter was allowed to vary randomly in each stratum. Hence, $a_{2, i}, a_{2, i j}$ and $a_{2, i j k}$ represent the random effect of $\alpha_{2}$ at the site, tree and disc levels, respectively. Due to the fact that correlation among random effects approached unity $(>0.97)$ when models were fitted with multiple random terms, a single random term was preferred in this and all subsequent models (Pinheiro and Bates 2000).

Trends in the normalised residuals of Eq. (2) when plotted against annual ring width indicated an increasing influence of ring width at higher cambial ages (Fig. 2). However, accounting for this effect in the logistic function proved problematic. Integrating the ring width term into the $\alpha_{1}$ parameter of Eq. (2) had the effect of altering only the rate of decline in MFA, but did not influence either the initial value near the pith or the asymptotic mature wood value. Similarly, allowing parameter $\alpha_{2}$ of Eq. (2) to vary with ring width had the same effect on MFA at all values of cambial age. Furthermore, including the ring width term in the $\alpha_{0}$ parameter had the effect of changing only the initial values of MFA but had no effect at higher cambial ages. For this reason, an alternative model, in the form of a modified Michaelis-Menten equation, was used in subsequent model fits. This equation is often used to model enzyme kinetics, but has also been used to predict the radial variation of MOE in Scots pine (Auty and Achim 2008). In the current study, the function used was a standard Michaelis-Menten equation with an added intercept term:

$y_{i j k l}=\frac{\beta_{0} \cdot \mathrm{CA}_{i j k l}}{\beta_{1}+\mathrm{CA}_{i j k l}}+\beta_{2}+b_{2, i}+b_{2, i j}+b_{2, i j k}+\varepsilon_{i j k l}$

where $\beta_{0}, \beta_{1}$ and $\beta_{2}$ are the fixed effects parameters to be estimated. In this equation, $\beta_{1}$ represents the rate parameter and $\beta_{2}$ the intercept, while the lower asymptote is given by $\beta_{0}+\beta_{2}$. The random effects of $\beta_{2}$ at the site, tree and disc levels are given by $b_{2, i}, b_{2, i j}$ and $b_{2, i j k}$, respectively.

3.3 Inclusion of annual ring width as an explanatory variable

In order to incorporate the increasing influence of ring width at higher cambial ages, the $\beta_{0}$ parameter of Eq. (3) was allowed to vary as a function of ring width. This had the effect of changing the asymptotic mature wood value of MFA without altering the initial value near the pith. This model was expressed as:

$\begin{aligned} y_{i j k l}= & \frac{\left(\gamma_{0}+\gamma_{3} \cdot \mathrm{RW}_{i j k l}\right) \mathrm{CA}_{i j k l}}{\gamma_{1}+\mathrm{CA}_{i j k l}}+\gamma_{2}+c_{2, i}+c_{2, i j}+c_{2, i j k}(4) \\ & +\varepsilon_{i j k l}\end{aligned}$

where $\mathrm{RW}_{i j k l}$ is the width (millimetres) of the $l$ th annual ring of the $k$ th disc from the $j$ th tree at the $i$ th site, $\gamma_{0} \ldots \gamma_{3}$ are the fixed effects parameters, and $c_{2, i}, c_{2, i j}$ and $c_{2, i j k}$ represent the random effects of $\gamma_{2}$ at the site, tree and disc levels, respectively. The site-level random effects estimate for Eq. (4) was negligible with a very wide $95 \%$ confidence interval, which justified its omission from the final model.

\subsection{Specification of variance function and correlation} structure

With the addition of the fixed effects, the assumption of independent, normally distributed within-group errors was 
Fig. 2 Normalized residuals of the logistic function given by Eq. (2) plotted against annual ring width. The loess smoothing function clearly shows the increasing trend in the residuals with ring width in older annual rings

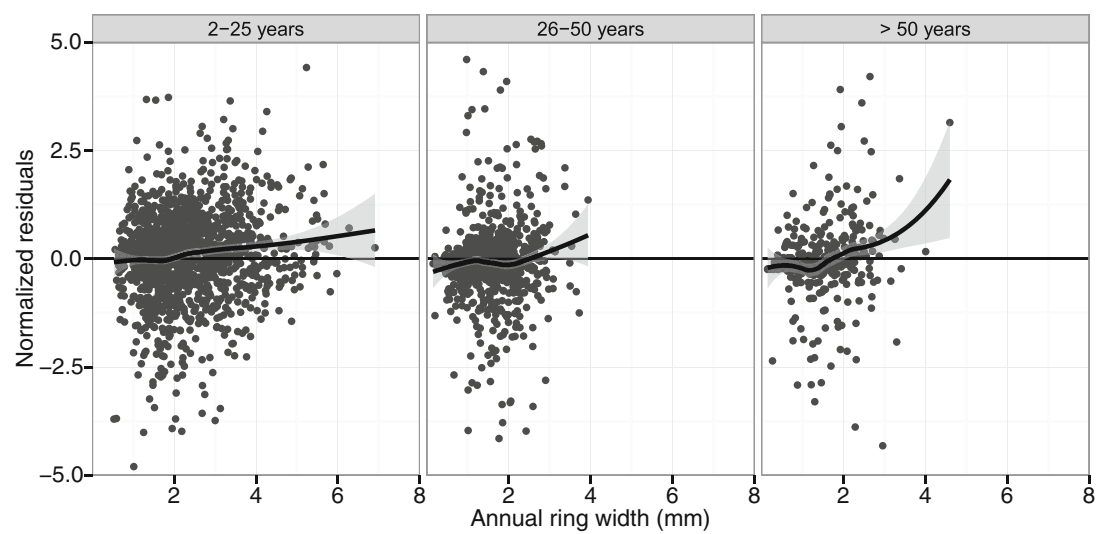

relaxed to accommodate heteroscedasticity and serial correlation $\varepsilon_{i j k l} \sim N\left(0, \sigma_{e}{ }^{2} \Lambda_{i j k l}\right)$, where $\Lambda_{i j k}$ are positive-definite matrices parameterized by a set of fixed parameters $\lambda$. In this study, heteroscedasticity was modelled as a power function of the absolute values of cambial age. The variance model and variance function, respectively, are given by:

$\operatorname{Var}\left(\varepsilon_{\mathrm{ijk}}\right)=\sigma^{2}\left|\mathrm{CA}_{\mathrm{ijk}}\right|^{2 \delta_{\mathrm{ijk}}}, \mathrm{g}\left(\mathrm{CA}_{\mathrm{ijk}}, \delta\right)=\left|v_{\mathrm{ijk}}\right|^{\delta_{\mathrm{jik}}}$

where $\mathrm{CA}_{i j k}$ is cambial age (years) and $\delta_{i j k}$ are the variance parameters for the site, tree and disc grouping levels, respectively. In addition, a first-order autoregressive correlation structure AR(1) was applied to model correlation among observations at successive cambial ages within each grouping factor. This model expresses the current observation as a linear function of previous observations plus a homoscedastic noise term centred at 0 , and is assumed to be independent of previous observations:

$\varepsilon_{t}=\phi_{1} \varepsilon_{t-1}+\ldots+\phi_{p} \varepsilon_{t-p}+\alpha_{t}$

where $\varepsilon_{t}$ is an observation at time $t, \phi$ is the single correlation parameter and $p$ is the number of past observations included in the autoregressive model (in this case, $p=1$ ). The lag-1 correlation parameter $\phi$ decreases exponentially with the lag, or distance between two observations, and takes values between -1 and 1 (Pinheiro and Bates 2000).

\section{Results}

The variance components of the intercept-only model showed that within-stem variation accounted for over $90 \%$ of the total observed variation in MFA, comprising $35 \%$ between-disc variation and $56 \%$ ring-level and residual variance. Between-tree differences represented just over $7 \%$ of the total, while site-to-site variation accounted for just $2 \%$ of the total variation given by Eq. (1). The fixed effects parameter estimates and standard deviation of the random effects for Eq. (4) are presented in Table 2.
In general, each successive model gave a lower AIC value and a higher log-likelihood (Table 3), indicating an improved fit. The final model containing the fixed effects of cambial age and annual ring width, given by Eq. (4), gave the lowest AIC, highest log-likelihood and overall highest fit indices and lowest error statistics than the other models (Table 3). The fixed effects of Eq. (4) were able to explain $63.4 \%$ of the variation in MFA in the data, increasing to 72.2 and $82.9 \%$ with the inclusion of the tree- and disclevel random effects, respectively. The corresponding values from the fixed effects of Eqs. (2) and (3) were 57.5 and $62.2 \%$, respectively (Table 3 ). The site random effect estimate was close to zero and not significant in the final model. Figure 3 shows predictions from Eq. (4) for different average ring widths of $0.5,4$ and $8 \mathrm{~mm}$, showing the increasing influence of growth rate on MFA at higher cambial ages, consistent with the patterns observed in Fig. 2.

Error statistics calculated from the fixed effects of Eq. (4) were $2.0^{\circ}$ and $14.7 \%$ for the mean absolute error and mean percentage error, respectively (Table 3 ). The value of the correlation parameter $\phi$ for Eq. (4) was -0.513 , indicating a relatively high correlation between successive annual rings.

Table 2 Parameter estimates, associated standard errors, $p$-values and standard deviation of the random effects estimates for the final model of MFA variation given by Eq. (4)

\begin{tabular}{lllll}
\hline Fixed parameters & Estimate & SE & $t$-value & $p$-value \\
$\gamma_{0}$ & -33.872 & 3.315 & -10.219 & $<0.0001$ \\
$\gamma_{1}$ & 1.574 & 0.260 & 6.066 & $<0.0001$ \\
$\gamma_{2}$ & 44.197 & 3.402 & 12.990 & $<0.0001$ \\
$\gamma_{3}$ & 0.247 & 0.029 & 8.436 & $<0.0001$ \\
& & & & \\
Random parameters & Std. dev. & Level & & \\
$c_{2, i}$ & - & Site & & \\
$c_{2, i j}$ & 1.096 & Tree & & \\
$c_{2, i j k}$ & 1.435 & Disc & & \\
$\varepsilon_{i j k l}$ & 7.728 & Residual & & \\
\hline
\end{tabular}


Table 3 AIC, log-likelihood, fit indices ( $R^{2}$-fixed plus random effects levels) and error statistics for the fitted MFA models given by Eqs. (2)-(4)

\begin{tabular}{|c|c|c|c|c|c|c|c|c|}
\hline \multirow[t]{2}{*}{ Model } & \multirow[t]{2}{*}{ AIC } & \multirow[t]{2}{*}{ Log-likelihood } & \multicolumn{4}{|c|}{ Fit indices $\left(R^{2}\right)$} & \multicolumn{2}{|c|}{ Model errors } \\
\hline & & & Fixed & Site & Tree & Disc & $|E|$ & $E \%$ \\
\hline Eq. (2) & $6,208.3$ & $-3,095.1$ & 0.575 & 0.575 & 0.666 & 0.796 & 2.16 & 16.1 \\
\hline Eq. (3) & $6,172.2$ & $-3,077.1$ & 0.622 & 0.634 & 0.717 & 0.823 & 2.08 & 15.0 \\
\hline Eq. (4) & $6,102.6$ & $-3,042.3$ & 0.633 & 0.633 & 0.722 & 0.829 & 2.03 & 14.7 \\
\hline
\end{tabular}

Mean absolute error $(|E|)$ and mean percentage error $(E \%)$ were calculated from the fixed part of each model

There were no observed trends in the normalized residuals from Eq. (4) when plotted against the explanatory variables and the predicted values of MFA (not shown), indicating a good overall fit to the data.

\section{Discussion}

The range of MFA values observed in this study (approximately $8^{\circ}$ to $34^{\circ}$ ) was similar to those found in other conifer species, including Scots pine (Lichtenegger et al. 1999), loblolly pine (Jordan et al. 2005; Megraw 1985) and Sitka spruce (McLean et al. 2010). Competing hypotheses have been proposed to explain radial variation in wood properties (Lachenbruch et al. 2011). One possible explanation for the large degree of within-tree variation in MFA is that young trees need the flexibility associated with low stiffness and high MFA in order to be able to reduce wind loading and therefore minimise the risk of stem breakage. As trees grow in size, they subsequently need to be able to withstand the large compressive and gravitational forces generated from their enlarging stems and crowns (Lachenbruch et al. 2011; Nicoll et al. 2006; Hale et al. 2012). This shift in requirements reflects a possible 'strategy for mechanical optimisation' (Lichtenegger et al. 1999) as a tree matures, and results in

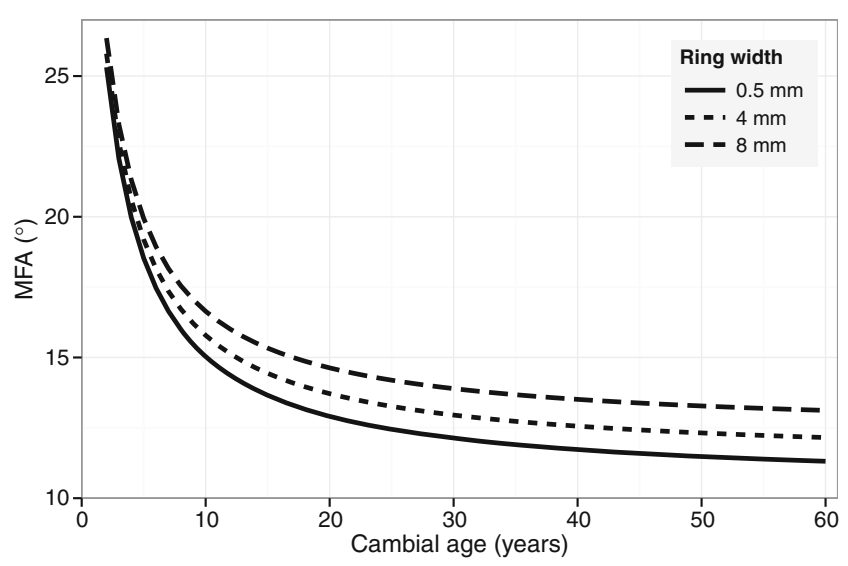

Fig. 3 Mean predicted MFA as a function of cambial age using Eq. (4) for average ring widths of $0.5,4$ and $8 \mathrm{~mm}$ the creation of a juvenile core in the tree with rapidly changing characteristics and generally lower stiffness (Burdon et al. 2004; Mansfield et al. 2009). A complementary explanation may also relate to the need to maintain hydraulic safety in young trees, which have less well-developed root systems and lower water storage capacity (Gartner 1995; Domec and Gartner 2002). In this case, the higher MFA of juvenile wood cells may allow for greater collapse resistance under the higher negative pressures required for water transport to the foliage (Lachenbruch et al. 2011).

The relatively small parameter estimate associated with annual ring width in the current study is consistent with previous studies, which also reported a small positive effect of growth rate on MFA (Lindström et al. 1998; Herman et al. 1999; Wimmer et al. 2002; Sarén et al. 2004). Radial growth rate, as expressed through site factors such as temperature, rainfall, fertilisation and initial stocking, was positively correlated to MFA in Norway spruce (Lindström et al. 1998). Similarly, in the juvenile wood of red pine (Pinus resinosa Ait.), Deresse et al. (2003) found that an increase in ring width resulted in larger MFA values and reduced strength and stiffness of small clearwood specimens. Lasserre et al. (2009) found that MFA was negatively correlated with stem slenderness in $P$. radiata clones, with trees planted at narrow initial spacing having significantly lower MFA values than those planted at wide spacings.

In the current study, the inclusion of annual ring width in the final model allowed us to separate the effects of cambial age and radial growth rate in trees of the same age but with different dimensions (i.e. different social status). An examination of the residuals from the model including only cambial age (Fig. 2) revealed that the positive effect of growth rate on MFA increased with cambial age, which was well accounted for by the use of the Michaelis-Menten equation. This effect could be related to the observed decrease in MFA across a single annual ring from earlywood to latewood tracheids (McMillin 1973; Cave and Walker 1994), and is therefore consistent with the observed increase in the proportion of earlywood in the rings of fast-grown trees (Ulvcrona and Ulvcrona 2011). The variation in MFA between earlywood and latewood has been shown to be more pronounced in the mature wood of both Scots pine 
and loblolly pine (Megraw et al. 1998; Krauss 2010), although Lichtenegger et al. (1999) observed the opposite trend in Norway spruce trees. Our results are consistent with the observation that growth rate has little influence on the inherent changes in wood properties with ring age in juvenile wood (Larson et al. 2001). This has also been reported by Zobel and Sprague (1998), who reported many similarities in the wood properties of narrow and wide rings of the same age in the juvenile zone. An increase in growth rate after the period of juvenile wood formation is therefore likely to have a greater influence on MFA than it would in younger annual rings.

McMillin (1973) also found a positive effect of growth rate on MFA, but only in trees with higher specific gravity, indicating a possible interaction between the growth rate effects on different wood properties. Even though the effects of site and silviculture on MFA may be small (Donaldson 2008), the non-significance of the site random effect in the final model was most likely due to the small number of sites in this study, rather than a true indication that site factors do not influence MFA. While some studies have reached the latter conclusion (e.g. Shuler et al. 1989; Donaldson 1996), others have postulated that observed differences between sites might be related to seed provenance (Jordan et al. 2006, 2007) or the dominant effect of genotype over environmental factors (Nakada et al. 2003). From this, it is clear that more information is required in order to separate the effects on MFA of site, silviculture and genetics (Donaldson and Burdon 1995).

The high incidence of compression wood $(\mathrm{CW})$ in the sample dataset (more than $40 \%$ of the samples had abnormal radial MFA profiles with higher than expected values in some growth rings) is in accordance with the generally high levels of CW that are observed in UK-grown conifer species, which is assumed to be associated with the windy climate (Gardiner and Macdonald 2005). Compression wood is associated with poor stem form and contains wood with both higher density and higher MFA values which negatively affect end-use characteristics such as stiffness, strength and shrinkage (Walker and Butterfield 1996). Therefore, fitting the model to data from samples containing no compression wood might lead to an overestimation of the predictive power of the model and an underestimation of the model bias, and would be unrepresentative of the resource.

\section{Conclusions}

This study has shown that radial patterns of variation in Scots pine microfibril angle are similar to those reported for other commercially important softwood species. The large observed within-stem variation in MFA poses challenges for the wood processing industry because changes in the overall proportion of juvenile wood due to fast growth or shorter rotations might be expected to have a negative impact on structural timber yields. In addition to the variation with cambial age, there was a positive influence of growth rate on MFA, as expressed through annual ring width, and this effect was larger at higher cambial ages. This was accounted for in the final model by allowing the effect of growth rate to increase with cambial age. The inclusion of radial growth increment in the final model will facilitate linkages with growth models to predict the effects of different silvicultural scenarios on MFA and other wood properties.

Acknowledgments Thanks to Sven-Olof Lundqvist, Åke Hansson and Lars Olsen at Innventia, Stockholm, for training in the use of the SilviScan-3 instrument. To Forest Research staff and Technical Services Unit for assistance with the extensive programme of field work: Shaun Mochan, Elspeth Macdonald, Steve Osborne, Andy Kennedy, Colin McEvoy, Alistair Macleod, Sandy Bowran, Calum Murray, Colin Smart and Steve O' Kane. Thanks also to Will Anderson (Seafield Estates), Steve Connolly (Cawdor Forestry) and Forestry Commission Scotland for the site access and sample trees.

Funding This project was funded by the Scottish Forestry Trust and Forest Research as part of the first author's doctoral thesis for the University of Aberdeen. The SilviScan work was partly funded by the European Cooperation in Science and Technology (COST) programme, under the Short-Term Scientific Mission initiative. Thanks to Professor John Barnett and Dr. Karin Hofstetter, the respective chairs of COST Actions E50 and FP0802.

\section{References}

Achim A, Gardiner B, Leban J-M, Daquitaine R (2006) Predicting the branching properties of Sitka spruce grown in Great Britain. NZ J For Sci 36:246-264

Akaike H (1974) A new look at the statistical model identification. IEEE Trans Autom Control 19:716-723

Alteyrac J, Cloutier A, Zhang SY (2006) Characterization of juvenile wood to mature wood transition age in black spruce (Picea mariana (Mill.) BSP) at different stand densities and sampling heights. Wood Sci Technol 40:124-138

Auty D, Achim A (2008) The relationship between standing tree acoustic assessment and timber quality in Scots pine and the practical implications for assessing timber quality from naturally regenerated stands. Forestry 81:475-487

Auty D, Weiskittel AR, Achim A, Moore JR, Gardiner BA (2012) Influence of early re-spacing on Sitka spruce branch structure. Ann For Sci 69:93-104

Barnett JR, Bonham VA (2004) Cellulose microfibril angle in the cell wall of wood fibres. Biol Rev 79:461-472

Bendtsen BA, Senft J (1986) Mechanical and anatomical properties in individual growth rings of plantation-grown eastern cottonwood and loblolly pine. Wood Fiber Sci 18:23-38

Burdon RD, Kibblewhite RP, Walker JCF, Megraw RA, Evans R, Cown DJ (2004) Juvenile versus mature wood: a new concept, orthogonal to corewood versus outerwood, with special reference to Pinus radiata and P. taeda. Forest Sci 50:399-415

Cameron AD, Lee SJ, Livingston AK, Petty JA (2005) Influence of selective breeding on the development of juvenile wood in Sitka spruce. Can J For Res 35:2951-2960 
Cave ID (1969) The longitudinal Young's modulus of Pinus radiata. Wood Sci Technol 3:40-48

Cave ID, Walker JCF (1994) Stiffness of wood in fast-grown plantation softwoods: the influence of microfibril angle. For Prod J 44:43-48

Clark A III, Daniels RF, Jordan L (2006) Juvenile/mature wood transition in loblolly pine as defined by annual ring specific gravity, proportion of latewood, and microfibril angle. Wood Fiber Sci 38:292-299

Cown DJ, Herbert J, Ball RD (1999) Modelling Pinus radiata lumber characteristics. Part I: mechanical properties of small clears. NZ J For Sci 29:203-213

Cown DJ, Ball RD, Riddell MJC (2004) Wood density and microfibril angle in 10 Pinus radiata clones: distribution and influence on product performance. NZ J For Sci 34:293-315

Deresse T, Shepard RK, Shaler SM (2003) Microfibril angle variation in red pine (Pinus resinosa Ait.) and its relation to the strength and stiffness of early juvenile wood. For Prod J 53:34-40

Domec JC, Gartner B (2002) Age- and position-related changes in hydraulic versus mechanical dysfunction of xylem: inferring the design criteria for Douglas-fir wood structure. Tree Physiol 22:91-104

Donaldson LA (1992) Within-and between-tree variation in microfibril angle in Pinus radiata. NZ J For Sci 22:77-86

Donaldson LA (1996) Effect of physiological age and site on microfibril angle in Pinus radiata. IAWA J 17:421-429

Donaldson L (2008) Microfibril angle: measurement, variation and relationships: a review. IAWA J 29:345-386

Donaldson LA, Burdon RD (1995) Clonal variation and repeatability of microfibril angle in Pinus radiata. NZ J For Sci 25:164-174

Downes GM, Nyakuengama JG, Evans R, Northway R, Blakemore P, Dickson RL, Lausberg M (2002) Relationship between wood density, microfibril angle and stiffness in thinned and fertilized Pinus radiata. IAWA J 23:253-266

Evans R (1999) A variance approach to the X-ray diffractometric estimation of microfibril angle in wood. Appita J 52:283-289

Evans R, Ilic J (2001) Rapid prediction of wood stiffness from microfibril, angle and density. For Prod J 51:53-57

Evans R, Downes GM, Menz D, Stringer S (1995) Rapid measurement of variation in tracheid dimensions in a radiata pine tree. Appita $\mathrm{J}$ 48:134-148

Gardiner B, Macdonald E (2005) Compression wood in conifers-the characterisation of its formation and its relevance to timber quality, in European Union-Framework Programme FP5-Quality of Life and Management of Living Resources, QLRT-2000-00177, p. 376

Gardiner B, Leban J-M, Auty D, Simpson HL (2011) Models for predicting the wood density of British-grown Sitka spruce. Forestry 84:119-132

Gartner BL (1995) Patterns of xylem variation within a tree and their hydraulic and mechanical consequences. In: Gartner BL (ed) Plant stems: physiological and functional morphology. Academic, New York, pp 125-149

Hale SE, Gardiner BA, Wellpott A, Nicoll A, Achim A (2012) Wind loading of trees: influence of tree size and competition. Eur J For Res 131:203-217

Herman M, Dutilleul P, Avella-Shaw T (1999) Growth rate effects on intra-ring and inter-ring trajectories of microfibril angle in Norway spruce (Picea abies). IAWA J 20:3-22

Houllier F, Leban J-M, Colin F (1995) Linking growth modelling to timber quality assessment for Norway spruce. For Ecol Manag 74:91-102

Jordan L, Daniels RF, Clark A III, He R (2005) Multilevel nonlinear mixed-effects models for the modeling of earlywood and latewood microfibril angle. Forest Sci 51:357-371

Jordan L, Re R, Hall DB, Clark A III, Daniels RF (2006) Variation in loblolly pine cross-sectional microfibril angle with tree height and physiographic region. Wood Fiber Sci 38:390-398
Jordan L, He R, Hall DB, Clark A III, Daniels RF (2007) Variation in loblolly pine ring microfibril angle in the southeastern United States. Wood Fiber Sci 39:352-363

Kennedy RW (1995) Coniferous wood quality in the future: concerns and strategies. Wood Sci Technol 29:321-338

Krauss A (2010) Variation in the microfibril angle in tangential walls of pine wood tracheids (Pinus sylvestris L.). Wood Res-Slovak $55: 7-12$

Lachenbruch B, Moore JR, Evans R (2011) Radial variation in wood structure and function in woody plants, and hypotheses for its occurrence. In: Meinzer FC, Lachenbruch B, Dawson TE (eds) Size- and age-related changes in tree structure and function. Tree physiology, volume 4. Springer, London

Larson PR (1969) Wood formation and the concept of wood quality. Yale University School of Forestry Bulletin 74, p. 54

Larson PR, Kretschmann DE, Clark AI, Isebrands JG (2001) Formation and properties of juvenile wood in southern pines: a synopsis. USDA Forest Products Laboratory, General Technical Report FPL-GTR-129. USDA, Madison, p 42

Lasserre J, Mason E, Watt M, Moore J (2009) Influence of initial planting spacing and genotype on microfibril angle, wood density, fibre properties and modulus of elasticity in Pinus radiata D. Don corewood For Ecol Manag 258:1924-1931

Lee SJ (1999) Improving the timber quality of Sitka spruce through selection and breeding. Forestry 72:123-133

Lenz P, MacKay J, Rainville A, Cloutier A, Beaulieu J (2011) The influence of cambial age on breeding for wood properties in Picea glauca. Tree Genet Genomes 7:641-653

Lichtenegger H, Reiterer A, Stanzl-Tschegg SE, Fratzl P (1999) Variation of cellulose microfibril angles in softwoods and hardwoods - a possible strategy of mechanical optimization. J Struct Biol 128:257-269

Lindström MJ, Bates DM (1990) Nonlinear mixed effects models for repeated measures data. Biometrics 46:673-687

Lindström H, Evans JW, Verrill SP (1998) Influence of cambial age and growth conditions on microfibril angle in young Norway spruce (Picea abies [L.] Karst.). Holzforschung 52:573-581

Lundgren C (2004) Microfibril angle and density patterns of fertilized and irrigated Norway spruce. Silva Fenn 38:107-117

Macdonald E, Gardiner B, Mason W (2010) The effects of transformation of even-aged stands to continuous cover forestry on conifer $\log$ quality and wood properties in the UK. Forestry 83:1-16

Mansfield SD, Parish R, Di Lucca CM, Goudie J, Kang K-Y, Ott P (2009) Revisiting the transition between juvenile and mature wood: a comparison of fibre length, microfibril angle and relative wood density in lodgepole pine. Holzforschung 63:449-456

McLean JP, Evans R, Moore JR (2010) Predicting the longitudinal modulus of elasticity of Sitka spruce from cellulose orientation and abundance. Holzforschung 64:495-500

McMillin CW (1973) Fibril angle of loblolly pine wood as related to specific gravity, growth rate, and distance from pith. Wood Sci Technol 7:251-255

Megraw RA (1985) Wood quality factors in loblolly pine. The influence of tree age, position in tree, and cultural practice on wood specific gravity, fiber length, and fibril angle. TAPPI Press, Atlanta

Megraw RA, Leaf G, Bremer D, Butterfield BG (1998) Longitudinal shrinkage and microfibril angle in loblolly pine. In: Butterfield BG (ed) Microfibril angle in wood. Proc. IAWA/IUFRO Intn. workshop on the significance of microfibril angle to wood quality. University of Canterbury, Christchurch, pp 27-61

Meylan BA (1972) The influence of microfibril angle on the longitudinal shrinkage-moisture content relationship. Wood Sci Technol 6:293-301

Moore J, Achim A, Lyon A, Mochan S, Gardiner B (2009a) Effects of early re-spacing on the physical and mechanical properties of Sitka spruce structural timber. For Ecol Manag 258:1174-1180 
Moore J, Mochan SJ, Brüchert F, Hapca AI, Ridley-Ellis DJ, Gardiner BA, Lee SJ (2009b) Effects of genetics on the wood properties of Sitka spruce growing in the UK: bending strength and stiffness of structural timber. Forestry 82:491501

Nakada R, Fujisawa Y, Hirakawa Y (2003) Effects of clonal selection by microfibril angle on the genetic improvement of stiffness in Cryptomeria japonica D. Don Holzforschung 57:553-560

Nicoll BC, Gardiner BA, Rayner B, Peace AJ (2006) Anchorage of coniferous trees in relation to species, soil type and rooting depth. Can J For Res 36:1871-1883

Panshin AJ, de Zeeuw C (1980) Textbook of wood technology, 4th edn. McGraw-Hill, New York, p 772

Parresol BR (1999) Assessing tree and stand biomass: a review with examples and critical comparisons. Forest Sci 45:573-593

Pinheiro JC, Bates DM (2000) Mixed-effects models in S and S-PLUS. Springer, New York

Pinheiro J, Bates D, DebRoy S, Sarkar D, R Core team (eds) (2012) nlme: linear and nonlinear mixed effects models. $\mathrm{R}$ package $\mathrm{v}$. 3.1-105

R Development Core Team (2012) R: a language and environment for statistical computing. R Foundation for Statistical Computing, Vienna

Sarén M-P, Serimaa R, Andersson S, Saranpää P, Keckes J, Fratzl P (2004) Effect of growth rate on mean microfibril angle and crosssectional shape of tracheids of Norway spruce. Trees-Struct Funct $18: 354-362$
Shuler CE, Markstrom DD, Ryan MG (1989) Fibril angle in young growth ponderosa pine as related to site index, dbh, and location in tree. USDA Forest Service Research Note RM-492

Timmell TE (1986) Compression wood in gymnosperms, vol 1-3. Springer, Berlin

Ulvcrona T, Ulvcrona KA (2011) The effects of pre-commercial thinning and fertilization on characteristics of juvenile clearwood of Scots pine (Pinus sylvestris L.). Forestry 84:207-219

Vainio U, Andersson S, Serimaa R, Paakkari T, Saranpää P, Treacy M, Evertsen J (2002) Variation of microfibril angle between four provenances of Sitka spruce (Picea sitchensis [Bong.] Carr.). Plant Biol 4:27-33

Verkasalo E, Leban (2002) MOE and MOR in static bending of small clear specimens of Scots pine, Norway spruce and European fir from Finland and France and their prediction for the comparison of wood quality. Pa Puu-Pap Tim 84:332-340

Walker JCF, Butterfield BG (1996) The importance of microfibril angle for the processing industries. N Z J For 40:34-40

Watt MS, Zoric B, Kimberley MO, Harrington J (2011) Influence of stocking on radial and longitudinal variation in modulus of elasticity, microfibril angle, and density in a 24-year-old Pinus radiata thinning trial. Can J For Res 41:1422-1431

Wimmer R, Downes GM, Evans R (2002) Temporal variation of microfibril angle in Eucalyptus nitens grown in different irrigation regimes. Tree Physiol 22:449-457

Zobel BJ, Sprague JR (1998) Juvenile wood in forest trees. Springer, Berlin 